\title{
Acute biochemical and Hematological responses to Bur dizzo castration in West African Dwarf bucks
}

\author{
Olaifa Abayomi Kayode ${ }^{1 *}$, Akpan Matthew Obot $^{2}$ \\ ${ }^{1}$ Department of Veterinary Surgery and Reproduction, University of Ibadan, Nigeria \\ ${ }^{2}$ Department of Veterinary Anatomy, University of Ibadan, Nigeria \\ Accepted 10 January, 2017
}

Castration has been shown to elicit physiological stress, inflammatory reactions, pain-associated behaviour, suppression of immune function, and a reduction in performance to varying degrees. The responses to castration using Burdizzo were investigated in four male West African Dwarf (WAD) goats hourly over a period of 3 hours. The bucks were castrated with Burdizzo clamp, blood samples were collected by jugular venipuncture for biochemical, hematological and hormonal analyses. The hematological values showed significant decreases $(\mathrm{P}<0.05)$ in $\mathrm{PCV}, \mathrm{Hb}$, Rbc, neutrophil throughout the period, while the White blood cell count decreased significantly 1 hour post castration. Respiratory rate increased significantly $(P<0.05)$ throughout the post castration period of study, while the rectal temperature significantly increasing $(P<0.05)$ for just an hour post castration. Cortisol level rose significantly $(P<0.05)$ throughout the study period. Testosterone and estrogen levels fell after an hour though non-significantly $(P>0.05)$ but later rose significantly $(P<0.05)$ during the second and third hour post castration. The serum biochemistry changes observed include a significant rise $(P<0.05)$ in AST, ALT, urea and Creatinine after 1 hour upon castration, but the values later significantly decreased $(P<0.05)$ after the 2 nd and 3rd hours. The serum electrolytes increased significantly $(P<0.05)$ an hour post castration when compared with the pre castration values and later decreased significantly $(P<0.05)$ at the 2 nd and 3 hours post castration in comparison to the 1 st hour value. There was a non-significant $(P>0.05)$ increase in heart rate 1 hour post castration before returning to the pre castration value. This study concluded that the effects of three hours post burdizzo castration on hematological and biochemical profile fluctuated significantly in all the values under study and this calls for clinical surveillance among surgeons when such animals are brought for surgery during the acute period of castration. Also, this study will make information available for clinicians and researchers.

Keywords: Burdizzo, Castration, Hematology, Biochemistry, Serum

Introduction

Goats are one of the most essential food-producing animal species in developing countries and an integral part of a traditional crop livestock production (Seyoum, 2002).

\footnotetext{
${ }^{*}$ Corresponding author email:akolaifa@yahoo.com
}

Castration means a process which stops or reduces the function of the testes leading to sterilization (Fisher and Knight, 2001). The castration of male goats is a routine practice in many countries aimed at stopping the production of male hormones and sperms, preventing mating after age of puberty, producing animal to be easier to handle with less aggressiveness and improving meat quality (Molony et al., 1995). Also to avoid 
unwanted pregnancies and mating of young females before they are of adequate size and age for pregnancy and parturition and reduce goaty smell in males (Burciage et al., 2006).

The common techniques used for castration are Burdizzo, elastration, ligation of spermatic cord and chemical castration (Coetzee et al., 2010). Burdizzo procedure requires the buck to be restrained as the burdizzo device is clamped on the spermatic cord above the testicles. Each spermatic cord is crushed separately. This action severs the blood supply to the testicles causing them to degenerate. Post-castration discomfort or pain from the use of the burdizzo is comparable with other castration methods (Robertson et al., 1994).Castration has been shown to elicit physiological stress, inflammatory reactions (indicated by acute phase proteins), pain-associated behaviour, suppression of immune function, and a reduction in performance (Fisher et al., 1997; Ahmed and Ahmed, 2011) to varying degrees. Castrations also affect growth and carcass composition as it alters metabolism (Solomon et al., 1991). The chronic effects of burdizzo castration on hematological and biochemical parameters in goats after 4 weeks have been earlier reported (Olaifa and Opara, 2011). Burdizzo castration has been shown to have no effect on most of feedlot performance traits and blood metabolites (Nasr et al., 2011). Previous reports showed an increase in two acute-phase proteins (APP) at an earlier time (days 1, 3, and 7 post-castration) in younger animals (Earley and Crowe, 2002; Ting et al., 2003; Pang et al., 2006). The effect of castration on average daily weight gain in goats has not been consistent. Daily weight gains of castrated goats were either lower (Allan and Holst, 1989), higher (Mackenzie, 1970) or unchanged (Koyuncu et al., 2007), compared to intact goats.

Hitherto, there is dearth of information on short or immediate term effects of bloodless burdizzo castration on hematological, biochemical and serum electrolytes in West African Dwarf goats. Hence, the need to study these effects within the first three hours post castration since such animals can be presented for surgical intervention within such hours post castration. Also, this study will make information available for clinicians and researchers for reference purposes.

\section{Materials and Methods}

\section{Experimental animals}

Four intact adult West African Dwarf bucks weighing between 8 to $14 \mathrm{~kg}$ were acclimatized for one week before commencement of this study. The individual pens were cleaned and disinfected prior to the arrival of the animals. Upon arrival, they were examined and dewormed using Levamisole ${ }^{\circledR}$ and de-ticked using
Asuntol an organophosphate compound. They were also placed on antibiotic therapy for 5 days by intramuscular administration and fed daily on a $12 \%$ protein ration, fresh grass and water ad libitum.

\section{Castration procedure}

The bucks were restrained with the hind limbs held apart and scrotal area exposed for correct application of the Burdizzo castrator. The instrument was applied laterally onto the scrotal neck behind the goat. The cord was held laterally in the scrotal neck by first finger and thumb, with the second hand directing the position of the jaws slowly, until they were about 8-10 mm apart to grip the skin and cord firmly. Rapid closure was ordered and maintained for 15-30 seconds, during which the cord was correctly crushed (Olaifa and Opara, 2011).

\section{Collection of blood samples}

$2.5 \mathrm{ml}$ of blood was collected by jugular venipuncture using a sterile needle and syringe both for hematology and serum analyses. The first set of blood samples were collected prior to castration and then hourly for 3 hours after castration. The samples were collected in the morning when the animals were calm and the ambient temperature was low so as to reduce stress related consequences. Thereafter, the samples were immediately taken to the laboratory for analyses after proper storage in an ice pack.

\section{Analyses of blood samples}

The blood samples collected for haematology were evaluated for packed cell volume (PCV) using the haematocrit method (Jain and Schalm, 1986). Haemoglobin concentration was evaluated using the cyanomethaemoglobin method (Schalm et al., 1975). Red blood cell count was determined by the haematocytometry method (Jain and Schalm, 1986). Total white blood cell (WBC) counts and differential leucocyte counts were estimated according to Coles (1989). Serum urea and Creatinine levels was determined using photoelectric colorimeter (Coles, 1989). Aspartate aminotransferase (AST) and alanine aminotransferase (ALT) activities were measured using a colorimetric method (Reitman and Frankel 1957). The serum electrolyte levels were evaluated using flame photometry (Jones, 1995).

\section{Statistical analysis}

Data collected were subjected to statistical analysis using ANOVA, followed by Turkey's multiple comparison. 
Table 1: Hematological values of WAD bucks before and after Burdizzo castration

\begin{tabular}{|c|c|c|c|c|}
\hline \multirow[t]{2}{*}{ Parameter } & \multirow[t]{2}{*}{ Pre-castration } & \multicolumn{3}{|c|}{ Post castration } \\
\hline & & 1 hour & 2 hours & 3 hours \\
\hline PCV (\%) & $48 \pm 0.41^{\mathrm{ab}}$ & $46.25 \pm 0.48^{\mathrm{a}}$ & $44.25 \pm 0.48^{\mathrm{a}}$ & $44.75 \pm 0.75^{\mathrm{a}}$ \\
\hline $\mathrm{Hb}(\mathrm{gm} / \mathrm{l})$ & $16.05 \pm 0.44^{\mathrm{ab}}$ & $14.83 \pm 0.08^{\mathrm{a}}$ & $14.6 \pm 0.23^{\mathrm{a}}$ & $14.63 \pm 0.17^{\mathrm{a}}$ \\
\hline Wbc $\left(\right.$ cell $\left./ \mathrm{mm}^{3}\right)$ & $10000 \pm 187.1^{\mathrm{ab}}$ & $11150 \pm 64.55^{\mathrm{ac}}$ & $12625 \pm 225^{a}$ & $13188 \pm 390.7^{a}$ \\
\hline $\mathrm{Rbc}\left(\right.$ cell $\left./ \mathrm{mm}^{3}\right)$ & $9063 \pm 174.9^{\mathrm{ab}}$ & $8450 \pm 64.55^{a b}$ & $7830 \pm 47.08^{\mathrm{a}}$ & $7875 \pm 253.7^{\mathrm{a}}$ \\
\hline Platelet(cell $\left./ \mathrm{mm}^{3}\right)$ & $595000 \pm 6455^{b c}$ & $635000 \pm 6455^{b c}$ & $683750 \pm 14913^{b}$ & $850000 \pm 21985^{b}$ \\
\hline Neutrophils (\%) & $69.25 \pm 0.75^{\mathrm{ac}}$ & $58.25 \pm 0.48^{\mathrm{bc}}$ & $62.25 \pm 0.75^{b c}$ & $53.75 \pm 1.60^{\mathrm{a}}$ \\
\hline Leucocytes (\%) & $30.5 \pm 0.65^{c}$ & $41.5 \pm 0.29^{\mathrm{bc}}$ & $37.75 \pm 0.75^{\mathrm{bc}}$ & $45.5 \pm 2.02^{b}$ \\
\hline
\end{tabular}

Values are mean \pm standard error of mean. Means on the same row with different superscripts are significantly different $(P<0.05)$.

Table 2: Serum biochemistry of WAD buck before and after Burdizzo castration

\begin{tabular}{lcccc}
\hline Parameters & Pre-castration & \multicolumn{3}{c}{ Post-castration } \\
\cline { 3 - 5 } & & $\mathbf{1}$ hour & 2 hours & 3 hours \\
\hline AST (iu/L) & $11.25 \pm 0.75 \mathrm{~b}$ & $14 \pm 0.41 \mathrm{ba}$ & $11.74 \pm 0.75 \mathrm{~b}$ & $10.75 \pm 0.48 \mathrm{bc}$ \\
ALT (iu/L) & $7.75 \pm 0.48 \mathrm{~b}$ & $10.5 \pm 0.29 \mathrm{ab}$ & $9.25 \pm 0.48 \mathrm{a}$ & $7.25 \pm 0.48 \mathrm{~b}$ \\
Urea (mg/dl) & $15.25 \pm 1.60 \mathrm{ab}$ & $20.25 \pm 0.48 \mathrm{a}$ & $14.5 \pm 1.19 \mathrm{~b}$ & $13.75 \pm 1.03 \mathrm{c}$ \\
Creatinine (mg/dl) & $0.53 \pm 0.05 \mathrm{ab}$ & $0.75 \pm 0.06 \mathrm{a}$ & $0.48 \pm 0.05 \mathrm{~b}$ & $0.43 \pm 0.05 \mathrm{c}$ \\
\hline
\end{tabular}

Values are mean \pm standard error of mean. Means on the same row with different superscripts are significantly different $(P<0.05)$. AST- Aspartate Transaminase ALT-Alanine Transaminase

Table 3: Serum electrolytes of WAD bucks before and after Burdizzo castration

\begin{tabular}{|c|c|c|c|c|}
\hline \multirow[t]{2}{*}{ Parameters } & \multirow[t]{2}{*}{ Pre-castration } & \multicolumn{3}{|c|}{ Post-castration } \\
\hline & & 1 hour & 2 hours & 3 hours \\
\hline $\mathrm{Na}+(\mathrm{mmol} / \mathrm{L})$ & $134 \pm 1.78 \mathrm{ab}$ & $140 \pm 0.41 \mathrm{a}$ & $133.8 \pm 0.85 b$ & $131.8 \pm 1.03 \mathrm{c}$ \\
\hline $\mathrm{Cl}-(\mathrm{mmol} / \mathrm{L})$ & $97.5 \pm 1.44 a b$ & $108 \pm 1.08 \mathrm{a}$ & $95 \pm 2.0 b$ & $93.75 \pm 2.4 \mathrm{c}$ \\
\hline $\mathrm{K}+(\mathrm{mmol} / \mathrm{L})$ & $3.23 \pm 0.10 a b$ & $3.93 \pm 0.08 a$ & $3.23 \pm 0.07 b$ & $3.28 \pm 0.07 c$ \\
\hline $\mathrm{Ca} 2+(\mathrm{mg} / \mathrm{dl})$ & $6.5 \pm 0.29 a$ & $6.5 \pm 0.29 a$ & $6.0 \pm 0.40 \mathrm{a}$ & $5.75 \pm 0.25 a$ \\
\hline $\mathrm{Cu} 2+(\mathrm{mg} / \mathrm{dl})$ & $3.75 \pm 0.75 a$ & $6.0 \pm 0.41 \mathrm{a}$ & $4.0 \pm 0.58 a$ & $3.75 \pm 0.48 a$ \\
\hline Zinc (mg/dl) & $2.75 \pm 0.48 \mathrm{a}$ & $3.5 \pm 0.29 a$ & $3.25 \pm 0.25 a$ & $4.5 \pm 0.29 a b$ \\
\hline $\mathrm{Mg} 2+(\mathrm{mg} / \mathrm{dl})$ & $5.25 \pm 0.48 a$ & $6.5 \pm 0.29 a$ & $4.75 \pm 0.25 \mathrm{ab}$ & $4.25 \pm 0.25 \mathrm{bc}$ \\
\hline
\end{tabular}

Values are mean \pm standard error of mean. Means on the same row with different superscripts are significantly different $(\mathrm{P}<0.05)$

Values of $\mathrm{P}<0.05$ were considered statistical significant and were presented as Mean \pm standard error of mean.

\section{Results}

The Packed cell volume (PCV), Hemoglobin concentration $(\mathrm{Hb})$ and red blood cell count (RBC) decreased significantly $(P<0.05)$ post castration compared with pre castration value. The white blood cell (WBC), platelets and leucocytes increased significantly $(\mathrm{P}<0.05)$ after 2 , 3hours castration as compared with pre castration (Table 1). The serum biochemistry changes observed includes a significant rise in AST, ALT, urea and Creatinine after 1 hour upon castration, but the values later significantly decreases after 2 and 3 hours as compared with 1 hour post castration (Table 2). Sodium ion $\left(\mathrm{Na}^{+}\right)$, Chloride ion $\left(\mathrm{Cl}^{-}\right)$, potassium ion $\left(\mathrm{K}^{+}\right)$and magnesium ion $\left(\mathrm{Mg}^{2+}\right)$ increased significantly 1 hour post castration as compared with pre castration value and decreased significantly 2 and 3 hours post castration as compared with 1 hour post castration. No significant changes in Calcium ion $\left(\mathrm{Ca}^{2+}\right)$ and copper ion $\left(\mathrm{Cu}^{2+}\right)$ but there was a non-significant increase in $\mathrm{Cu}^{2+} 1$ hour post castration. Zinc ion $\left(\mathrm{Zn}^{2+}\right)$ showed a significant increase 3 hours post castration compared with pre castration value (Table 3). There was a non-significant increase $(P>0.05)$ in heart rate 1 hour post castration which later returned to the pre castration level. Respiratory rate increased significantly $(\mathrm{P}<0.05)$ throughout the post castration period while the rectal temperature significantly increased 
Table 4: Heart rate, respiratory rate and rectal temperature of WAD bucks before and after Burdizzo castration

\begin{tabular}{lcccc}
\hline Parameters & Pre-castration & \multicolumn{3}{c}{ Post-castration } \\
\cline { 3 - 5 } & & 1 hour & 2 hours & 3 hours \\
\cline { 2 - 5 } Heart rate(Beats/min) & $112 \pm 1.83 \mathrm{a}$ & $114.5 \pm 0.65 \mathrm{a}$ & $107 \pm 3.03 \mathrm{a}$ & $112 \pm 1.83 \mathrm{a}$ \\
Resp rate(Breaths/min) & $49.75 \pm 0.85 \mathrm{bc}$ & $81.75 \pm 0.85 \mathrm{a}$ & $81.75 \pm 0.85 \mathrm{a}$ & $72.75 \pm 1.25 \mathrm{ab}$ \\
Rect. Temp (0 C) & $38.83 \pm 0.14 \mathrm{ab}$ & $39.9 \pm 0.28 \mathrm{a}$ & $39.43 \pm 0.15 \mathrm{ab}$ & $39.05 \pm 0.19 \mathrm{ab}$ \\
\hline
\end{tabular}

Values are mean \pm standard error of mean. Means on the same row with different superscripts are significantly different $(P<0.05)$

Table 5: Hormones level of WAD bucks before and after castration

\begin{tabular}{lcccc}
\hline Parameters & Pre-castration & \multicolumn{3}{c}{ Post-castration } \\
\cline { 3 - 5 } & & $\mathbf{1 ~ h o u r}$ & 2 hours & 3 hours \\
\hline Testosterone (iu/L) & $1.48 \pm 0.28^{\mathrm{b}}$ & $0.93 \pm 0.05^{\mathrm{ba}}$ & $1.89 \pm 0.23^{\mathrm{b}}$ & $2.73 \pm 0.14^{\mathrm{bc}}$ \\
Estrogen (iu/L) & $0.75 \pm 0.16^{\mathrm{b}}$ & $0.33 \pm 0.05^{\mathrm{ab}}$ & $0.73 \pm 0.13^{\mathrm{a}}$ & $1.23 \pm 0.08^{\mathrm{b}}$ \\
Cortisol (iu/L) & $5.25 \pm 0.75^{\mathrm{ab}}$ & $8.25 \pm 0.25^{\mathrm{a}}$ & $8.75 \pm 1.03^{\mathrm{a}}$ & $13 \pm 1.23^{\mathrm{c}}$ \\
\hline
\end{tabular}

Values are mean \pm standard error of mean. Means on the same row with different superscripts are significantly different $\quad(P<0.05)$

an hour post castration(Table 4). The testosterone and estrogen levels decreased at the $1^{\text {st }}$ hour but later increased significantly at the $3^{\text {rd }}$ hour. The cortisol level significantly $(\mathrm{P}<0.0 .05)$ rises throughout the hour of the study (Table 5).

\section{Discussion}

Castration is any procedure that removes the testicles surgically, damaging them irreparably or causing them to atrophy by stricture of the blood supply (Currah et al., 2009). There are various castration methods used in animals, which include physical, chemical and hormonal methods (Rajkumar, 2013).Haematological parameters are good indicators of the physiological status of animals (Khan and Zafar, 2005). Several non-genetic factors including castration affecting haematological parameters of farm animals have been observed (Svoboda et al., 2005; Xie et al., 2013). PCV, Hemoglobin concentration $(\mathrm{Hb})$ and $\mathrm{RBC}$ were significantly reduced at 1,2 and 3hours as compared to pre-castration level in this study. These findings corroborate the findings reported by Kelani and Durotoye, 2002; Hassan, 2010; Zha et al., 2013 and Gofur et al., 2014. Testosterone has the ability to increase erythropoiesis (red blood corpuscles production) in the kidneys, and a higher red blood corpuscles (RBCs) count (Hassan, 2010). Therefore, acute deficiency of testosterone of the goats might have caused the significant decrease in RBC and PCV and $\mathrm{Hb}$ since the testis is the major producer of testosterone.

The total WBC, Platelets and leucocytes increased significantly in the post castration values as compared to pre castration values. This profound effects on leucocytes indices is in agreement with the findings of AL-Zghoul et al., 2008; Hassan, 2010. Castration has been shown to elicit physiological stress, anti-inflammatory reactions (indicated by acute phase proteins), pain-associated behaviour, suppression of immune function, and a reduction in performance (Ahmed and Ahmed, 2011; Fisher et al., 1997; Molony et al., 1995) to varying degrees. The acute phase response (APR) is a nonspecific component of innate immunity, which may respond to infection, inflammation, tissue damage, or stress (Fisher et al., 2001; Hughes et al., 2014). Biological responses associated with the APR include fever, production of acute phase proteins by hepatocytes, and increases in circulating WBC (Carroll and Forsberg, 2007).

The castration procedure has been reported to elicit varying degrees of pain in animals (Udegbunam et al., 2013). Pain in animals is associated with changes in physiological and biochemical parameters, as a result of changes in plasma levels of catecholamines (Molony and Kent, 1997). Painful stimulations have been associated with increased heart and respiratory rates as a result of increased activities of the sympathetic nervous system (Molony and Kent, 1997; Udegbunam et al, 2013). This might probably explain the significant rise in heart rate, respiratory rate and rectal temperature observed in this study in post castration values when compared with the pre castration values.

Testosterone and estrogen levels dropped 1 hour post castration and later increased significantly $(\mathrm{P}<0.05) 2,3$ hours post castration, this might be due to compensatory response of the body as part of homeostatic control while cortisol increase significantly post castration. Fundamentally, severe pain, whether it is acute or chronic, is a severe stressor that activates the hypothalamic-pituitary-adrenal-thyroid-gonadal 
(HPATG) system, which is the major stress control mechanism of the body (Cutolo et al., 1999; Tennant, 2000). The critical pain-control hormones that are produced in glands outside the central nervous system are cortisol, pregnenolone, dehydroepiandrosterone (DHEA), progesterone, testosterone, estrogen, and thyroid (Pednekar and Mulgaonker, 1995; Jain et al., 1991; Aloisi and Bonifazi, 2006). Therefore pain stimulation of the hormone system that might be due to the burdizzo castration causes these adrenal and gonad hormone levels to elevate in the serum. The persistent increase in cortisol values seen in this study follows what was reported by Murata, 1997, and Courboulay et al., 2010.Serum level of different electrolytes is an important indicator of the physiological status of the animal as they are involved in most of the body functions; such as muscle contraction, nerve conduction, body fluid homeostasis and maintenance of blood pH (Ashis, 2005). The acute increase in serum electrolytes values is in agreement with the results obtained by Mamman et al., (2014) where they observed an increase in sodium and potassium values in surgically castrated Red Sokoto bucks which later returned to normal values and further decreased to values lower than the normal range values in bucks. This may be due to reactive changes associated with stress during and few hours after castration.

The Urea concentration increased significantly after 1 hour and later decreases significantly 2, 3 hours post castration. This was similar to reports of Nasr et al., 2001 who reported a higher blood urea level for intact than that of castrated animal. This may be due to the fact that the usual quantity of testosterone hormone secreted by the testes during active sexual life increased the digestion efficiency of protein resulting in increased blood urea level (Lee et al., 1990) and acute testosterone decline decreases the protein digestion efficiency resulting in decreased urea level. The increased level of urea observed following an hour post castration could apparently due to elevated cortisol concentration as established by several authors (Stull and Rodiek, 2000; Kannan et al., 2000; Odore et al., 2004). Stress is known to cause an increase in plasma urea, which indicates an increase in protein and nucleic acids breakdown in the muscles, due to increase in cortisol concentration and during stressful conditions (Packer et al., 2007; Guardia et al., 2009).

The ALT, AST, and creatinine concentrations were similar to the findings of Mohammad et al., 2008 following castration Awassi lambs. These changes are likely due to increased catabolic breakdown of tissue and dehydration as a result of post-operative stress. It could be concluded from these findings that acute response to burdizzo castration elicit pain which reduces the hematology, increase the white blood cell, increase stress hormone and fluctuates serum electrolytes and this calls for clinical surveillance among surgeons when such animals are brought for surgery during the acute phase. And values obtained from this study will serve as reference data to researchers in related areas of study.

\section{References}

Ahmed SA, Ahmed EA (2011). Behavioural responses of castrated bucks kids at different ages by using different methods of castration. J. Am. Sci. 7, 200-209.

Allan CJ, Holst PJ(1989). Comparison of growth and dressing percent between intact male, castrated male and female kids of Australian bush goats. Small Rumin Res 2: 63-68.

Aloisi AM, Bonifazi M (2006). Sex hormones, central nervous system and pain. Horm Behav;50:1-7.

AL-Zghoul MBF, AL-Rukibat RK, Talafha AQ, Ababneh O, Ismail ZAB (2008). Cellular and some biochemical changes in blood and peritoneal fluid constituents in awassi lambs following elective castration. American J. Anim. Vet. Sci., 3(1): 23-27.

Burciage RL, Step DL, Holland BP, McCurdy MP, Krehbiel CR (2006). Castration in goats: Technique and animal welfare issues. Compend. Cont. Educ. Pract. Veterinarian, 24 (9): 512-515.

Carroll JA, Forsberg NE (2007). Influence of stress and nutrition on cattle immunity. Vet. Clin. North Am.: Food Anim. Pract. 23:105-149.

Coetzee JF, Nutsch AL, Barbur LA, Bradburn RM (2010). A survey of castration methods and associated livestock management practices performed by bovine veterinarians in the United States.

Coles EH (1989). Veterinary Clinical Pathology, $4^{\text {th }}$ edition (W.B. Saunders Co., USA, 1989).

Currah JM, Hendrick SH, Stooley JM (2009). The behavioral assessment and alleviation of pain associated with castration in beef calves treated with fluxinin meglumine and caudal lidocaine epidural anesthesia with epinephrine. Canadian Vet. J. 50: 375-382.

Cutolo M, Foppiani L, Prete C (1999). Hypothalamic-pituitaryadrenocortical axis function in premenopausal women with rheumatoid arthritis not treated with glucocorticoids. J Rheumatol. 1999; 26:282-8.

Earley B, Crowe MA (2002). Effects of ketoprofen alone or in combination with local anesthesia during the castration of bull calves on plasma cortisol, immunological, and inflammatory responses. J. Anim. Sci. 80, 1044-1052.

Fisher AD, Crowe MA, O'Nuallain EM, Monaghan ML, Prendiville DJ,O'Kiely Enright WJ (1997). Effects of suppressing cortisol following castration of bull calves on adrenocorticotropic hormone, in vitro interferonproduction, leukocytes, acutephase proteins, growth, and feed intake. J. Anim. Sci. 75, 1899-1908.

Fisher AD, Knight TW, Cosgrov GP (2001). Effect of surgical or banding castration on stress responses and behavior of bulls. Aust. Vet. J., 79: 279-284.

Guardia MD, Estany J, Balasch S, Oliver MA, Gispert M, Diestre A (2009). Risk assessment of skin damage due to pre-slaughter conditions and RYRI gene in pigs. Meat Sci. 81: 745-751.

Hassan AA (2010). Effect of castration on some physiological aspect in rats: Effect of testosterone hormone. J. Edu. Sci., 23(3): 28-39.

Hughes HD, Carroll JA, Sanchez CB, Richeson JT (2014). Natural variations in the stress and acute phase responses of cattle. Innate Immun. 20(8):888-896.

Jain NC, Schalm (1986). Veterinary Haematology, 4th edn.(Lea and Febiger, USA).

Jain R, Zwickler D, Hollander CS, (1991) Corticotropin-releasing factor modulates the immune response to stress in the rat. Endocrinology; 128:1329-36.

Kannan G, Terrill TH, Konakou B, Gazal OS, Gelaye S, Amoah EA, Samake $S$ (2000). Transportation of goats: Effects on physiological stress responses and live weights loss. J. Anim. Sci. 78: 1450 1457.

Kelani OL, Durotoye LA (2002). Haematological responses of the African giant rat (Cricetomis gambianus) to castration and androgen replacement. Vetreinarski Arhiv., 72(1): 39-49. 
Khan TA, Zafar F (2005). Haematological study in response to varying doses of estrogen in broiler chicken. Inter. J. Poul. Sci., 4(10): 748751.

Koyuncu M, Duru S, Kara Uzun S, Ozis S, Tuncel E(2007). Effect of castration on growth and carcass traits in hair goat kids under a semiintensive system in the south-Marmara region of Turkey. Small Rumin Res 72: 38-44, 2007.

Lee CY, Henricks DM, Skelley GC, Grimes LW (1990). Growth and Hormonal response of intact and castrated male cattle, Trenbolone Acetate and estadiol. J. Anim. Sci., 68: 2682-2689.

Mackenzie D(1970). Goat husbandry, Faber and Faber Limited, London Mamman MO, Aka LO, Ahmed A, Sa'idu B, Abubakar AA, Adamu U, Ibrahim HM, Garba B, Raji AA (2014) Short Term Comparative Analysis of Serum Electrolytes and Performance Characteristics of Castrated and Intact Red Sokoto Bucks. Tanzania Vet. J. 29 (1); $72-$ 79

Mohammad BF, AL-Zghoul, Raida K, AL-Rukibat, Abdelsalam Q, Talafha, Omar Ababneh, Zuhair A, Bani Ismail (2008). Cellular and Some Biochemical Changes in Blood and Peritoneal Fluid Constituents in Awassi Lambs Following Elective Castration American J. Anim. Vet. Sci., 3 (1): 23-27

Molony V, Kent JE, Robertson IS (1995). Assessment of acute and chronic pain after different methods of castration of calves. Appl Anim Behav Sci.;46:33-48.

Molony V, Kent JE (1997). Assessment of acute pain in farm animals using behavioral and physiological measurements. J. Anim. Sci., 75:266-272.

Murata H (1997). Effects of burdizzo castration on peripheral blood lymphocyte parameters in calves. Vet. J. 153, 229-231.

Nasr Al, Atta M, Elmahi MI, Mohammed AO (2011) Effect of castration on feedlot performance and some serum metabolites of Nubian male kids. roavs, 1 (2), 98-101

Odore R, Angelo AD, Badino P, Bellino C, Pagliasso S, RE G (2004). Road transportation affects blood hormone levels and lymphocyte glucocotocoid and B-adrenergic receptors concentration in calves. Vet. J. 168: $297-303$.

Olaifa Ak, Opara MN (2011) Haematological and Biochemical parameters of West African Dwarf bucks castrated by the Burdizzo method. Vet. Arhiv.; 81: 743-750

Pang WY, Earley B, Sweeney T, Crowe MA, (2006). Effect of carprofen administration during banding or burdizzo castration of bulls on plasma cortisol, in vitro interferon-y production, acutephase proteins, feed intake, and growth. J. Anim. Sci. 84, 351-359.

Parker AJ, Dobson GP, Fitzpatrick LA (2007). Physiological and metabolic effects of prophylactic treatment with the osmolytes glycerol and betaine on Bos indicus steers during long duration transportation. J. Anim. Sci. 85: 2916-2923.

Pednekar J, Mulgaonker VK (1995).Role of testosterone on pain threshold in rats. Indian J Physiol Pharmacol.; 39:423-4.

Rajkumar D (2013). Minimisation of pain in cattle castration with respect to method, age and pain relief. http://vip.vetsci.usyd.edu.au/contentUpload/content_3164/RajkumarD harshinee.pdf, retrieved 2013-03-22.

Reitman AG, Frankel S (1957). A colorimetric method for the determination of serum glutamic transaoxalecetic and glutamic pyruvic transaminases. American J. Clin Pathology 28: 56-63.

Robertson IS, Kent JE, Molony V (1994). Effect of different methods of castration on behaviour and plasma cortisol in calves of three ages. Res. Vet. Sci. 56, 8-17.

Schalm OW, Jain NC, Carrol E (1975). Veterinary Haematology 3rd Edition Lea and Febiger, Philadephia USA, 160-210

Seyoum S (2002). Economic of small ruminant meat production and consumption in Sub SaharanAfrica. International Livestock Centre for Africa, 2: $15-26$.

Solomon G, Fletcner I, Gizaw K, Yibrah Y (1991). Effects of castration and supplementary feeding on growth, carcass characteristics, and market value of Adal goats'. In: IAR Proceedings of the Fourth National Livestock Improvement Conference, Addis Ababa, Ethiopia. pp.159-164.
Stull CL, Rodiek AV (2000). Physiological responses of horses to 24 hours of transportation using a commercial van during summer conditions. J. Anim. Sci. 78: $1458-1466$.

Svoboda M, Eichlerova K, Horak V, Hradecky J (2005). Development of haematological indices in melanoma-bearing liběchov minipigs. Acta Veterinaria Brno., 74(4): 603-611.

Tennant $F(2000)$. Intractable pain is a severe stress state associated with hypercortisolemia and reduced adrenal reserve. Drug Alcohol Depend. 2000; 60(Suppl. 1):220-1.

Ting STL, Earley B, Hughes JML, Crowe MA (2003). Effect of ketoprofen, lidocaine local anaesthesia, and combined xylazine and lidocaine caudal epidural anaesthesia during castration of beef cattle on stress responses, immunity, growth and behaviour. J. Anim. Sci. 81, 1281-1293.

Udegbunam RI, Asuzu IU, Kene ROC, Udegbunam SO (2013). Evaluation of local anaesthetic efficacy of the crude extract of Sterculia tragacantha using West African Dwarf Goats Sokoto Journal of veterinary Sciences, 11(1): 13-21.

Xie L, Xu F, Liu S, Ji Y, Zhou Q, Wu Q(2013). Age- and sex-based hematological and biochemical parameters for Macaca fascicularis. PLoS ONE, 8(6): e64892. doi:10.1371/journal.pone.0064892.

Zha C, Moon DG, Park JK (2013). Effect of testosterone undecanoate on hematological profiles, blood lipid and viscosity and plasma testosterone level in castrated rabbits. Can. Urol. Assoc. J., 7(3-4): E221-225. 